\title{
GAMBARAN FAKTOR YANG MEMPENGARUHI NYERI PUNGGUNG BAWAH PADA BURUH KAPAL
}

\author{
${ }^{1}$ Rahma Ayu Wulandari \\ ${ }^{2}$ J. Maja. P.S \\ ${ }^{2}$ Herlyani Khosama
}

\author{
${ }^{1}$ Kandidat Skripsi Fakultas Kedokteran Universitas Samratulangi Manado \\ ${ }^{2}$ Bagian Neurologi Fakultas Kedokteran Universitas Samratulangi Manado \\ Email : rahmaayuwulandari10_072@yahoo.com
}

\begin{abstract}
Background: Low back pain (LBP) is a soreness on lower back area, can be donated to a local nor radicular pain or both. It can be experienced by anyone, at any age,and often causing disruption of daily activities, disability and productivity of sureffers.

Objectives: Reveal the affecting factors of low back pain (LBP) on ship labour at the port of Bitung City in 2013.

Methods: This is a desciptive study with cross-sectioanl and the total sample of 71 respondents.

Result: The results showed that the most perceived intensity of painful are the pain feels very slight which 22 respondents (31,0\%), the interpretation of modified oswetry scoring LBP showed the highest interpretation of respondents with minimal disability, that is 36 respondents $(50,7 \%)$, most respondents who have been experienced were the respondents who worked 3 hours per day or per ship arrival that is 20 respondents $(31,7 \%)$, LBP is the most numerous in the age beetwen 35-44 years is 25 respondents (39,0\%), the higest number of respondents were classified as normal range of body mass index with 25 respondents (39,7\%).
\end{abstract}

Keywords: Low back pain, Ship Labour, Modified Oswetry Scoring.

\section{ABSTRAK}

Latar Belakang: Nyeri Punggung bawah (NPB) adalah nyeri yang dirasakan di daerah punggung bawah, dapat merupakan nyeri lokal maupun nyeri radikular atau keduanya. NPB dapat dialami siapa saja, pada umur berapa saja, bahkan seringkali menyebabkan gangguan aktivitas sehari-hari, disabilitas dan produktifitas penderitanya.

Tujuan: Mengetahui gambaran faktor yang mempengaruhi NPB pada buruh kapal di pelabuhan Samudera Kota Bitung tahun 2013.

Metode: Penelitian ini bersifat deskriptif dengan pendekatan cross-sectional dengan jumlah sampel sebanyak 71 responden.

Hasil: Hasil penelitian menunjukkan Intensitas nyeri yang dirasakan paling banyak yaitu nyeri terasa sangat ringan yaitu 22 responden (31,0\%), Intepretasi Modified Oswetry Scoring NPB menunjukkan Intepretasi terbanyak pada responden dengan pembatasan aktivitas ringan yaitu 36 responden (50,7\%), Responden terbanyak yang merasakan nyeri adalah responden yang bekerja 3 jam perhari atau setiap kedatangan kapal yaitu 20 responden (31,7\%), NPB paling banyak terdapat pada usia antara 35-44 tahun yaitu 25 responden (39,0\%), Jumlah responden terbanyak adalah yang tergolong indeks massa tubuh kisaran normal yaitu 25 responden (39,7\%).

Kata Kunci: Nyeri Punggung Bawah, Modified Oswetry Scoring. 


\section{PENDAHULUAN}

Nyeri Punggung bawah (NPB) adalah nyeri yang dirasakan di daerah punggung bawah, dapat merupakan nyeri lokal maupun nyeri radikular atau keduanya. ${ }^{1}$ NPB merupakan keluhan muskuluskeletal yang sering dikeluhkan oleh pasien. Bahkan seringkali menyebabkan gangguan aktivitas sehari-hari, disabilitas dan produktifitas penderitanya. ${ }^{2}$ NPB dapat dialami siapa saja, pada umur berapa saja. Namun demikian keluhan NPB jarang dijumpai pada kelompok umur 0-10 tahun, hal ini mungkin berhubungan dengan beberapa faktor etiologi tertentu yang sering dijumpai pada usia yang lebih tua.Hampir 70-80\% penduduk di Negara maju pernah mengalami NPB. Setiap tahun 14-45\% orang dewasa menderita NPB, dan satu di antara 20 penderita harus di rawat dirumah sakit karena serangan akut. NPB sangat umum pada umur 35-55 tahun. ${ }^{1}$ Data epidemiologi mengenai NPB di Indonesia belum ada, namun diperkirakan 40\% penduduk pulau Jawa Tengah berusia diatas 65 tahun pernah menderita nyeri punggung, prevalensi pada lakilaki 18,2\% dan pada wanita 13,6\%. Insiden berdasarkan kunjungan pasien ke beberapa rumah sakit di Indonesia berkisar antara 3-17\%. ${ }^{3}$

Data di BLU Prof.dr. R.D. Kandou Manado, jumlah penderita NPB sebanyak 203 penderita (0,92\%) dari total 22037 seluruh penderita penyakit saraf yang datang di poliklinik saraf RSU. Prof. Dr. R. D. Kandou Manado pada periode 1 januari 2007 sampai dengan 31 desember 2008. Jumlah penderita NPB pada tahun 2007 dan 2008 yang terbanyak adalah usia 46 sampai 60 tahun dan yang terendah pada usia 15 sampai 30 tahun dan usia 75 tahun keatas. Jumlah penderita perempuan lebih banyak dibandingkan jumlah penderita laki-laki. Jumlah penderita NPB yang terbanyak pada tahun 2007 dengan pekerjaan sebagai pegawai negeri dan diikuti oleh pensiunan kemudian oleh ibu rumah tangga, sedangkan yang terbanyak pada tahun 2008 dengan pekerjaan sebagai pegawai negeri diikuti oleh ibu rumah tangga kemudian oleh pensiunan. ${ }^{4}$

Faktor risiko terjadinya NPB antara lain usia, indeks massa tubuh, kehamilan dan faktor psikologi. Seorang yang berusia lanjut akan mengalami NPB karena penurunan fungsi-fungsi tubuhnya terutama tulang, sehingga tidak lagi elastis seperti diwaktu muda. Sedangkan postur merupakan faktor pendukung NPB. Kesalahan postur seperti bahu melengkung ke depan, perut menonjol ke depan dan lordosis lumbal berlebihan dapat menyebabkan spasme otot (ketegangan otot). Hal ini merupakan penyebab terbanyak dari NPB. ${ }^{5}$

NPB juga terjadi oleh karena berbagai faktor, diantaranya faktor pekerjaan yang melibatkan aktivitas yang berlebihan seperti mengangkat benda yang berat. Khusunya hal tersebut terjadi pada kelompok pekerja buruh kapal, karena mengangkut barang turun dari kapal maupun sebaliknya menjadi tujuan dari para pekerja ini. Hal tersebut sering dilakukan para buruh kapal walaupun dengan 
kapasitas jumlah barang yang berlebihan dan posisi yang salah sehingga dapat memicu munculnya gejala NPB. Oleh karena itu penelitian ini akan mengemukakan tentang gambaran faktor yang mempengaruhi NPB pada buruh kapal yang bekerja di pelabuhan Samudera Kota Bitung.

\section{METODE PENELITIAN}

Penelitian ini bersifat deskriptif dengan pendekatan cross-sectional. Dilaksanakan di pelabuhan Samudera Kota Bitung, tepatnya di Terminal penumpang pelabuhan Samudera Kota Bitung pada bulan November-Desember 2013. Populasi dari penelitian ini adalah buruh kapal di pelabuhan Samudera Kota bitung yang masih aktif bekerja. Dengan jumlah populasi yaitu 237 orang. Dan sampel dari penelitian ini adalah khusunya buruh kapal yang mengangkat barang saat bekerja. Dengan menggunakan rumus slovin jumlah sampel yang didapat yaitu sebanyak 71 responden. Data dari penelitian ini diperoleh melalui observasi dan wawancara langsung pada responden dengan menggunakan alat bantu kuesioner penelitian. Kuesioner yang digunakan berdasarkan atas Modified Oswetry Low Back Pain Disability Questionnaire dan kuesioner tambahan yang terdiri dari beberapa pertanyaan yang dibuat untuk melengkapi hasil penelitian, kemudian data diolah dengan menggunakan SPSS ( Statistical Program for Social Science ) version 20.

\section{HASIL PENELITIAN}

Berdasarkan penelitian yang dilakukan jumlah buruh kapal yang bekerja di pelabuhan Samudera Kota Bitung berjumlah 237 pekerja dan yang menjadi responden pada penelitian ini adalah 71 responden didapatkan hasil sebagai berikut :

\section{Distribusi Responden berdasarkan Usia}

Berdasarkan karakteristik usia, responden terbanyak adalah responden dengan usia antara 35-44 tahun yaitu sebanyak 27 responden (38,0\%). Diikuti dengan usia 45-54 tahun yaitu 18 responden (25,4\%), 25-34 tahun yaitu 14 responden (19,7\%), 55-64 tahun yaitu 8 responden (11,3\%), 65-74 tahun yaitu 4 responden $(5,6 \%)$ dan tidak ada responden yang berusia antara 15-24 tahun dan $\geq$ 75 Tahun (0\%).

\section{Distribusi Responden berdasarkan Lama Bekerja}

Dilihat dari lama bekerja responden di pelabuhan Samudera Kota Bitung, didapatkan minimum 2 tahun, maximum 46 tahun dengan nilai rata-rata 17,80 tahun. 
Tabel 1. Distribusi Responden berdasarkan Intensitas Nyeri

\begin{tabular}{lcc}
\hline \hline \multicolumn{1}{c}{ Intensitas Nyeri } & Jumlah & $\begin{array}{c}\text { Persentase } \\
(\%)\end{array}$ \\
\hline Tidak merasa nyeri & 8 & $11,3 \%$ \\
Merasa nyeri & 63 & $88,7 \%$ \\
$\quad$ Nyeri terasa sangat ringan & 22 & $31,0 \%$ \\
Nyeri terasa ringan & 17 & $23,9 \%$ \\
Nyeri terasa agak berat & 11 & $15,5 \%$ \\
Nyeri terasa sangat berat & 9 & $12,7 \%$ \\
Nyeri terasa amat sangat & 4 & $5,6 \%$ \\
berat & & \\
Total & $\mathbf{7 1}$ & $\mathbf{1 0 0 \%}$ \\
\hline \hline
\end{tabular}

Pada tabel 1.dapat dilihat bahwa berdasarkan intensitas nyeri, responden terbanyak adalah nyeri terasa sangat ringan yaitu sebanyak 22 responden (31,0\%).

Tabel 2. InterpretasiModified Oswetry Scoring Nyeri Punggung Bawah

\begin{tabular}{|c|c|c|}
\hline Interpretasi & Jumlah & $\begin{array}{c}\text { Persentase } \\
\text { (\%) }\end{array}$ \\
\hline Tidak ada pembatasan aktivitas & 8 & $11,3 \%$ \\
\hline Pembatasan aktivitas ringan & 36 & $50,7 \%$ \\
\hline Pembatasan aktivitas sedang & 22 & $31,0 \%$ \\
\hline Pembatasan aktivitas berat & 4 & $5,6 \%$ \\
\hline Pembatasan aktivitas sangat berat & 1 & $1,4 \%$ \\
\hline Aktivitas terbatas di tempat tidur & 0 & $0 \%$ \\
\hline Total & 71 & $100 \%$ \\
\hline \multicolumn{3}{|c|}{$\begin{array}{l}\text { Pada tabel } 2 \text {. dapat dilihat bahwa berdasarkan intepretasi Modified Oswe } \\
\text { Scoring, responden terbanyak adalah pembatasan aktivitas ringan yaitu } 3 \\
\text { responden }(50,7 \%) \text {. }\end{array}$} \\
\hline \multicolumn{3}{|l|}{ Tabel 3. Nilai Rata-rata Jam Kerja Perhari } \\
\hline Tariabel Penelitian & Maximum & Mean \\
\hline Lama Kerja Perhari & $6 \mathrm{Jam}$ & 3,23 Jam \\
\hline
\end{tabular}


Pada tabel 3.dapat dilihat nilai rata-rata berdasarkan jam kerja perhari pada buruh kapal adalah 3,23 jam setiap kedatangan kapal.

\section{Bar Chart}
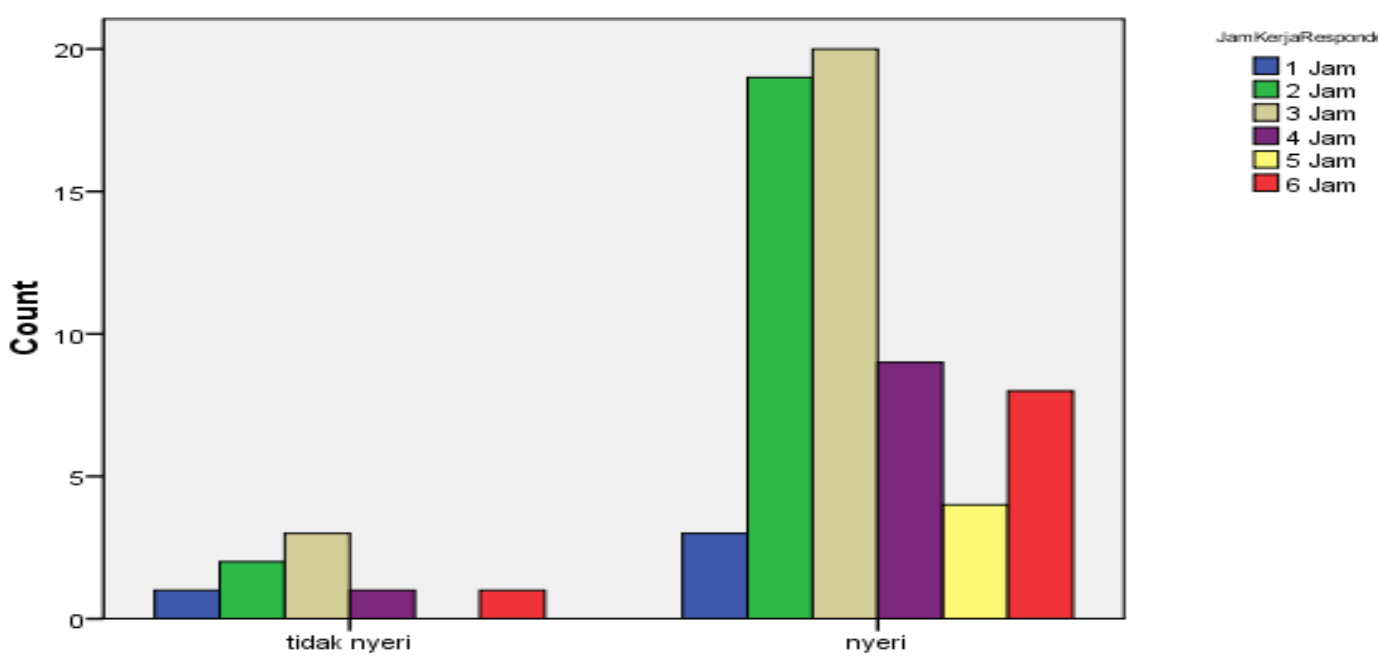

Jam kerja terbanyak pada reponden yang merasakan nyeri adalah responden yang bekerja 3 jam perhari atau setiap kedatangan kapal yaitu 20 responden (31,7\%), diikuti dengan responden yang berkerja 2 jam yaitu 19 responden (30,2\%), responden yang bekerja 4 jam yaitu 9 responden (14,3\%), responden yang bekerja 6 jam yaitu 8 responden (12,7\%), responden yang bekerja 5 jam yaitu 4 responden (6,3\%), dan terendah responden yang bekerja 1 jam yaitu 3 responden (4,8\%).

Tabel 4. Distribusi Nyeri berdasarkan Usia

\begin{tabular}{ccccc}
\hline \hline & \multicolumn{2}{c}{ Nyeri } & \multicolumn{2}{c}{ Tidak Nyeri } \\
Usia & Jumlah & $\%$ & Jumlah & $\%$ \\
\hline 15-24 Tahun & 0 & 0 & 0 & $0 \%$ \\
25-34 Tahun & 12 & $19,0 \%$ & 2 & $25,0 \%$ \\
35-44 Tahun & 25 & $39,7 \%$ & 2 & $25,0 \%$ \\
45-54 Tahun & 15 & $23,8 \%$ & 3 & $37,5 \%$ \\
55-64 Tahun & 8 & $12,7 \%$ & 0 & $0 \%$ \\
65-74 Tahun & 1 & $4,8 \%$ & 1 & $12,5 \%$ \\
$\geq$ 75 Tahun & 0 & $0 \%$ & 0 & $0 \%$ \\
Total & $\mathbf{6 3}$ & $\mathbf{1 0 0}$ & $\mathbf{8}$ & $\mathbf{1 0 0}$ \\
& & & & \\
\hline
\end{tabular}

Pada tabel 4. dapat dilihat bahwa responden terbanyak yang mengalami NPB adalah responden dengan usiaantara 35-44 tahun yaitu 25 responden (39,7\%). 
Tabel 5.Distribusi Nyeri berdasarkan Indeks Massa Tubuh

\begin{tabular}{ccccc}
\hline \hline & Nyeri & \multicolumn{3}{c}{ Tidak Nyeri } \\
Klasifikasi & Jumlah & $\%$ & Jumlah & $\%$ \\
\hline BB kurang & 5 & $7,9 \%$ & 1 & $12,5 \%$ \\
Kisaran normal & 25 & $39,7 \%$ & 2 & $25,0 \%$ \\
Berat badan lebih & & & & \\
Beresiko & 10 & $15,9 \%$ & 1 & $12,5 \%$ \\
Obese I & 16 & $25,4 \%$ & 2 & $25,0 \%$ \\
Obese II & 7 & $11,1 \%$ & 2 & $25,0 \%$ \\
Total & $\mathbf{6 3}$ & $\mathbf{1 0 0} \%$ & 8 & $\mathbf{1 0 0} \%$ \\
& & & & \\
\hline
\end{tabular}

Pada tabel 5. dapat dilihat bahwa responden terbanyak yang mengalami NPBberdasarkan indeks massa tubuh adalah indeks massa tubuh kisaran normal adalah 25 responden (39,7\%).

\section{PEMBAHASAN}

Pada penelitian ini terdapat 71 responden, didapatkan 63 responden yang mengalami NPB dan 8 responden yang tidak mengalami NPB. Dengan Intensitas nyeri (tabel IV.1) menunjukkan bahwa responden terbanyak adalah nyeri terasa sangat ringan yaitu 31,0\%. Namun hal tersebut berbeda dengan hasil penelitian yang dilakukan Santoso pada buruh gendong di Pasar Bandungan Kabupaten Semarang yang menunjukkan bahwa responden terbanyak dengan nyeri terasa berat $71,9 \%{ }^{6}$

Menurut interpretasi Modified Oswetry Scoring NPB (tabel IV.3) paling banyak responden dengan pembatasan aktivitas ringan yaitu 50,7\%. Hal tersebut dikarenakan oleh berbagai faktor yang mempengaruhi NPB berdasarkan penelitian yang telah dipaparkan diatas terbanyak kemampuan responden masih dalam batas normal sehingga hanya menyebabkan pembatasan aktivitas ringan. Sesuai dengan penelitian yang dilakukan Yapar pada tenaga kerja perusahaan pengelolah teh PT “X” di Kota Garut yang menunjukkan seluruh responden penelitian (30 responden) memiliki pembatasan aktivitas ringan. Sehingga hal tersebut menunjukkan bahwa seluruh tenaga kerja dapat melakukan aktivitas sehari-hari tanpa terganggu oleh gejala NPB. ${ }^{7}$

Berdasarkan jam bekerja perhari menunjukkan bahwa responden terbanyak yang mengalami NPB yaitu responden yang bekerja 3 jam $(32,4 \%)$ setiap kedatangan kapal. Hal tersebut sesuai dengan penelitian yang dilakukan oleh Nurwahyuni pada 76 pekerja bongkar muat barang pelabuhan Nusantara Kota Pare-pare tahun 2012 yang menunjukkan bahwa responden yang memiliki 
lama kerja tidak lama $(<8$ jam) lebih banyak mengalami nyeri punggung bawah $(93,4 \%)^{8}$

Berdasarkan usia (tabel IV.5) didapatkan NPB terbanyak pada responden yang berusia antara 35-44 tahun yaitu 39,7\%. Hal ini sesuai dengan sumber yang menyatakan bahwa NPB sangat umum pada usia 35-55 tahun. ${ }^{1}$ Dan sesuai dengan penelitian Sakinah pada pekerja batu bata di Kelurahan Lawawoi Kabupaten Sidrap Kelompok usia yang paling banyak adalah responden dengan kategori usia $>35$ tahun dengan presentasi 51,9\%. ${ }^{9}$

Indeks masa tubuh (Tabel VI.6) menunjukkan bahwa responden terbanyak yang mengalami NPB adalah responden yang tergolong klasifikasi indeks masa tubuh kisaran normal yaitu 39,7\%. Hal tersebut sesuai dengan penelitian yang dilakukan oleh Nurwahyuni pada 76 pekerja bongkar muat barang pelabuhan Nusantara Kota Pare-pare tahun 2012 yang menunjukkan bahwa responden dengan indeks masa tubuh normal lebih banyak yakni $80,3 \% .{ }^{8}$ Walaupun hasil yang didapatkan sesuai namun hal tersebut menunjukkan bahwa terdapat penurunan presentasi responden dengan indeks masa tubuh normal. Dan hal tersebut juga menunjukkan bahwa NPB dapat terjadi pada responden dengan IMT normal walaupun berdasarkan faktor risiko, kegemukan lebih sering menyebabkan beban yang menumpu pada vertebra di segmen lumbal menjadi sangat besar, sehingga menyebabkan kerusakan struktur vertebra yang dapat menyebabkan NPB. ${ }^{10}$

\section{KESIMPULAN DAN SARAN}

Intensitas nyeri yang dirasakan paling banyak yaitu nyeri terasa sangat ringan yaitu 22 responden (31,0\%), intepretasi Modified Oswetry Scoring NPB menunjukkan Intepretasi terbanyak pada responden dengan pembatasan aktivitas ringan yaitu 36 responden (50,7\%), responden terbanyak yang merasakan nyeri adalah responden yang bekerja 3 jam perhari atau setiap kedatangan kapal yaitu 20 responden (31,7\%), NPB paling banyak terdapat pada usia antara 35-44 tahun yaitu 25 responden (39,0\%), jumlah responden terbanyak adalah yang tergolong indeks massa tubuh kisaran normal yaitu 25 responden (39,7\%). Berdasarkan hasil yang telah didapatkan disarankan untuk melakukan penyuluhan dan sosialisasi mengenai faktor yang mempengaruhi NPB pada buruh kapal, bagi pihak pengawas buruh di pelabuhan Samudera Kota Bitung agar memberikan pelatihan pada pekerja tentang cara kerja yang baik dan perlu dilakukan penelitian lebih lanjut guna untuk lebih mengetahui hal-hal yang berhubungan dengan NPB. 


\section{DAFTAR PUSTAKA}

1. Mahadewa B. Diagnosis \& Tatalaksana Kegawat Daruratan Tulang Belakang. Edisi ke-1. Jakarta: CV Sagung Seto; 2009.h.156-88

2. Setiyohadi B. Kumpulan Makalah temu ilmiah Reumatologi. Jakarta: Fakultas Kedokteran Universitas Indonesia/RS. Dr. Ciptomangunkusumo; 2013.h.91-6.

3. Purnamasari H, Gunarso U, Rujito L. Overweight Sebagai Faktor Resiko Low Back Pain pada Pasien Poli Saraf RSUD PROF.DR. Margono Soekarjo Purwokerto. Mandala of Health. 2010; 4:26-32.

4. Soebhi T. Profil Penderita Nyeri Punggung Bawah di Poliklinik Saraf RSU.Prof Dr. R.D. Kandou Manado Periode 1 Januari 2007 sampai 31 Desember 2008. (KTIS).Manado: FK UNSRAT;2009.

5. Fathoni H, Handoyo, Girindra S. Hubungan Sikap dan Posisi Kerja Dengan Low Back Pain pada Perawat di RSUD Purbalingga. The Soedirman Journal of Nursing. 2009; 4:131-139.

6. Susanto N. Faktor-faktor yang Berhubungan dengan Keluhan Nyeri Pinggang pada Buruh gendong di pasar Bandungan Kabupaten Semarang. Jurnal Kesehatan Masyarakat 2013.2013;2.

7. Yapar S. Prevalensi Low Back Pain pada Tenaga Kerja Perusahan Pengolahan Teh PT. “X” di Kota Garut. (KTIS). Bandung: FK UK Maranatha: 2011.

8. Nurwahyuni. Faktor yang Berhubungan dengan Keluhan Nyeri Punggung Bawah pada Pekerja Bongkar Muat Barang Pelabuhan Nusantara Kota Pare-pare tahun 2012.(KTIS). Makassar: FKM UNHAS;2012.

9. Sakinah, Rafael D, Furqaan N, Faktor yang Berhubungan dengan Keluhan Nyeri Punggung Bawah pada Pekerja Batu-bata di Kelurahan Lawawoi Kabupaten Sidrap. (KTIS). Makassar: FKM UNHAS;2012.

10. Garnadi. Faktor Risiko Nyeri Punggung Bawah. 2012 (cited 2014 Jan 5). Diunduh dari : http://familiamedika.net/group-masalah-punggung/faktorrisiko-penyebab-keluhan-nyeri-punggung-bawah.html\#.Ut1LJShm7EY 